\title{
Siyah Karbon ile Stabilize Edilen Taban Zeminin Yol Esnek Üst Yapı Maliyetine Etkisi
}

\author{
Tacettin Geçkil ${ }^{1}$, Talha Sarıcı ${ }^{2}$, Bahadır Karabaş ${ }^{31}$ \\ 1* İnönü Üniversitesi, İnşaar Mühendisliği Bölümü, Malatya, Türkiye, (ORCID: 0000-0001-8070-6836), tacettin.geckil@inonu.edu.tr \\ 2 İnönü Üniversitesi, İnşaar Mühendisliği Bölümü, Malatya, Türkiye, (ORCID: 0000-0001-8488-5851), talha.sarici@ @inonu.edu.tr \\ 3 2'nci Ordu Komutanlığı, Malatya, Türkiye, (ORCID: 0000-0003-0416-9121), karabasbaha@ gmail.com
}

(İlk Geliş Tarihi 16 Ocak 2021 ve Kabul Tarihi 20 Mart 2021)

(DOI: 10.31590/ejosat.862682)

ATIF/REFERENCE: Geçkil, T., Sarııı, T. \& Karabaş, B. (2021). Siyah Karbon ile Stabilize Edilen Taban Zeminin Yol Esnek Üst Yap1 Maliyetine Etkisi. European Journal of Science and Technology, (23), 222-235.

\section{Öz}

Bu çalışmada, atık araç lastiklerden geri dönüşüm ürünü olarak elde edilen siyah karbonun, yol taban zemininin stabilizasyonunda kullanılmasının, esnek yol üst yapı tabaka kalınlıklarına ve maliyetine etkileri araştırılmıştır. Bu amaçla, ilk olarak zayıf zemin elek analizi, hidrometre, kıvam limitleri ve piknometre deneylerine tabi tutularak özellikleri belirlenmiştir. Daha sonra zemine ağırlıkça $\% 2,5 ; \% 5, \% 10, \% 15, \% 20$ oranlarında siyah karbon ilave edilerek stabilize karışım numuneleri hazırlanmıştır. Saf ve katkılı zemin numuneleri ASTM D698 standardına göre standart proktor deneyine tabi tutulduktan sonra numuneler, 1 ve 7 günlük kür süresi sonrasında ASTM D2166 standardına göre serbest basınç deneyine tabi tutulmuştur. Deney sonucunda en yüksek mukavemet değeri \%10 siyah karbon katkılı karışımlardan elde edilmiştir. Hazırlanan saf ve \%10 siyah karbon katkılı numuneler 1 ve 7 günlük kür sonrasında ASTM D1883 standardına göre Kaliforniya Taşıma Oranı (CBR) deneyine tabi tutulmuştur. CBR değerinin; \%10 siyah karbon katkısı ile, 1 günlük kür sonunda 1,28 kat arttırdığı ve 7 günlük kür sonunda 1,77 kat arttırdığı tespit edilmiştir. Bu CBR değerleri kullanılarak AASHTO 1993 yöntemine göre esnek yol üst yapı tabaka kalınlıkları tasarımı yapılmış ve üst yapı maliyetleri değerlendirilmiştir. Hesaplamalar neticesinde, siyah karbon ile stabilize edilen zeminlerin üst yapı maliyetlerinin, 1 günlük kür sonunda $\% 5,13$ oranında ve 7 günlük kür sonunda $\% 14,37$ oranında düşüş gösterdiği tespit edilmiştir.

Anahtar Kelimeler: Zayıf Zemin, Siyah Karbon, Stabilizasyon, CBR, AASHTO metodu.

\section{The Effect of Subbase Stabilized by Carbon Black on the Cost of Road Flexible Superstructure}

\begin{abstract}
In this study, the effects of using black carbon obtained as a recycling product from waste vehicle tires for stabilization of a road base floor on flexible road superstructure layer thickness and cost were investigated. Firstly, the properties of black carbon were determined by experimenting with weak soil sieve analysis, hydrometer consistency limits, and pycnometer test. Secondly, various mass ratios $(2.5 \%, 5 \%, 10 \%, 15 \%, 20 \%)$ of black carbon were added to the mixture of stabilization samples. Pure and mixture samples were experimented with by using a proctor test according to the ASTM D698 standards. After 1 and 7 days curing period, they were experimented with under an unconfined compression test according to the ASTM D2166 standards. Experimental results showed that the highest strength values were obtained from the mass ratio of the $10 \%$ black carbon mixture sample. These samples were experimented with under a CBR test according to the ASTM D1883 standards after 1 and 7 days curing period. CBR value; It was determined that it increased 1.28 times at the end of 1 day of cure and 1.77 times after 7 days of cure. Using these CBR values, according to the AASHTO 1993 method; flexible road superstructure layer thicknesses were designed and their costs were evaluated. As a result of the calculations; It was determined that in case of improvement with $10 \% \mathrm{C}$ by applying 1 and 7 days cure, the superstructure costs decreased by $5.13 \%$ and $14.37 \%$, respectively.
\end{abstract}

Key words: Weak soil, Carbon Black, Stabilization, CBR, AASHTO method.

${ }^{1}$ Corresponding Author: karabasbaha@gmail.com 


\section{Giriş}

Geçmişten günümüze; toplumların gelişmesi, yerleşim alanların büyümesi ve ticari faaliyetlerin yaygınlaşması ile birlikte karayolu ihtiyacı önemli ölçüde artmıştır. Bu ihtiyacın karşılanması maksadıyla karayollarının çeşitli iklim, arazi ve zemin şartlarında yapılması gerekebilmektedir. Yapılan etüt ve araştırmalar, tetkik edilen zeminlerin her zaman yol tasarımı için istenilen özelliklere sahip olmayabileceğini göstermektedir. $\mathrm{Bu}$ sebeple yapılacak yolun ekonomik ve güvenilir şekilde tasarlanması için yol altında kalan zeminin istenilen mühendislik özelliklerini sağlayacak şekilde stabilize edilerek güçlendirilmesi gerekir. Zemin stabilizasyonu için genellikle sönmüş kireç, bitüm ve çimento gibi malzemeler kullanılmaktadır. Ancak; son yıllarda atık ve geri dönüşüm ürünlerinin kullanılmasına yönelik çalışmalarda yapılmaya başlamıştır. Bu malzemeler kolay temini ve yapım maliyetlerini azaltmaları sebebiyle tercih edilmektedir. $\mathrm{Bu}$ kapsamda çeşitli atık malzemelerle stabilizasyon (iyileştirme) çalışmalarının yapıldığı görülmüştür. $\mathrm{Bu}$ tür ürünlerin değerlendirilmesinin ülke ekonomisi ve çevrenin korunmasına faydalı olacağı düşünülmektedir. Keskin (2004), yaptığı çalışmada farklı killi zeminleri kireç ile iyileştirmeyi amaçlamıştır. Çalışmada öncelikle zeminin kireç stabilizasyonuna uygun olup olmadığını laboratuar çalışmalarıyla belirlemiş ve daha sonra arazi deneyleri gerçekleştirmiştir. Kireç ile yapılan iyileştirme sonucunda CBR deneylerinde yeşil kilde 16 kat, kahverengi kilde ise 21 kat artış olduğu sonucuna ulaşmıştır [1]. Basha ve diğ.(2005), çalışmasında pirinç kabuğu külü ve çimento kullanarak kil bir zemini iyileştirilmeye çalışmışlardır. Pirinç kabuğu külü ve çimento ilavesinin maksimum kuru yoğunluğu azalttı̆̆ optimum su muhtevası değerini de arttırdığı sonucunu elde etmişlerdir. CBR değerinin; \%4 çimento ve $\% 5$ pirinç kabuğu külü kombinasyonu ile \%60 kadar arttığını tespit etmişlerdir [2]. Akbulut ve diğ. (2007), \%2 atık lastik lifi takviyeli killi zeminlerde yaptığ zeminlerin serbest basınç değerlerinin, killi zeminden 1,97 kat daha yüksek olduğunu tespit etmiştir [3]. Brooks (2009), yaptığ1 çalışmada uçucu kül ve pirinç kabuğu külünün zemin stabilizasyonunda kullanılabilirliğini araştırmıştır. Şişme potansiyeli olan kil zemine pirinç kabuğu külü ve uçucu kül ilave ederek, serbest basınç ve CBR deneyi yapmıştır. Uçucu kül oranın 0'dan \%25 artması ile kayma gerilmesinin \%105, şekil değiştirmenin ise $\% 50$ arttığını tespit etmiştir. Pirinç kabuğu külü oranın 0'dan \%12'ye artması ile CBR değerinin \%47, serbest basınç dayanımı değerinin \%97 arttığını belirlemiştir [4]. Keskin ve Laman (2012), kötü derecelenmiş ince kumu (SP) atık lastik parçacıkları ile iyileştirmeye çalışmışlardır. Karışımlarda atık lastik oranının; $\% 10$ ve $\% 15$ olması ile kayma mukavemetinde \%100 artış olduğunu, \%20'den daha fazla olması ile kayma mukavemetinde düşüş olduğunu belirlemişlerdir [5]. Shabana ve diğ. (2014), siltli kum zemini kırılmış Hindistan cevizi kabuğu ile iyileştirmeye çalışmışlardır. Yapılan çalışmada maksimim $1 \mathrm{~cm} 2$ yüzey alanına sahip $\% 16$ oranında kırılmış Hindistan cevizi kabuğu ile yapılan iyileştirmenin taşıma gücünü arttırdığı görülmüştür [6]. Yarbaşı (2016), yaptığı çalışmada kil bir zemini değişik boyutlarda $(1,18$ $\mathrm{mm} ; 2 \mathrm{~mm} ; 3,15 \mathrm{~mm}$ ) atık lastik ile iyileştirmeye çalışmıştır. Bu amaçla, 28 günlük kür sonunda yapılan serbest basınç deneyi sonucunda; \%0,5 atık lastik (1,18 mm.) karışımında \%35,3; $\% 0,5$ atık lastik $(2.00 \mathrm{~mm})$ karışımında $\% 8,6$ ve $\% 2$ atık lastik (3,15 mm.) karışımında ise \%14,2 mukavemet artışı olduğu belirlemiştir [7]. Karaman ve Ecemiş (2017) atık lastik kırpıntılarını ince kum (SP) ile karıştırarak hazırladığı numuneler ile sarsma tablası deneyleri yapmıştır. Karışımının sıvılaşma direncinin, temiz kumun sıvılaşma direncinden fazla olduğunu gözlemlemişlerdir. Bu durumun lastik kırpıntılarının suyu drene etmesinden kaynaklandığı sonucuna varmışlardır [8]. Işık ve Akbulut (2018) killi zemine ağırlıç̧a \%1, \%3, \%5 ve $\% 10$ oranında siyah karbon katarak, likit limit ve plastik limit deneyleri yapmıştır. Siyah karbon malzemesi artıkça likit limit ve plastik limitin azaldığını tespit etmiştir [9]. Kumar S.N ve diğ. (2019), kum zemine Hindistan'ın Andhra Pradesh eyaleti, Bobbili, Vizianagaram Dist. tesisinden temin edilen siyah karbon malzemesi karıştırarak karışımlar hazırlamışlardır. Siyah karbon oranının artıkça optimum su muhteviyatı değerinin arttığı, maksimum kuru birim ağırlığı değerinin azaldığını gözlemlemişlerdir. Ayrıca; yapılan CBR deneyinde optimum karışımım \%6 olduğu ve CBR değerini 1,2-1,5 kat arttırdığını tespit etmişlerdir [10]. Zemin stabilizasyonunda atık ve geri dönüşüm ürünlerinin kullanılması kapsamında; yılda yaklaşık 17 milyon ton kadar oluşan atık araç lastiklerinin bir geri dönüşüm malzemesi olarak birçok alanda kullanılmasına rağmen [11], yapılan literatür incelemesi neticesinde; atık araç lastiklerden elde edilen siyah karbonun zayıf zeminin stabilizasyonu için kullanılması durumunda, esnek yol üst yapısı kalınlık ve maliyetine etkilerinin araştırılmadığı görülmüştür.

$\mathrm{Bu}$ çalışmada, siyah karbon ile dayanımı arttırılan zayıf zeminin, esnek yol üst yapısı kalınlık ve maliyetine etkileri, yapılan deneysel çalışmalar ve hesaplamalar ile araştırılmıştır. $\mathrm{Bu}$ amaçla, saf zemin numunesine elek analizi, hidrometre deneyi, kıvam limitleri deneyleri, piknometre ve proktor deneyi yapılmıştır. Siyah karbonun $\% 2,5 ; \% 5, \% 10, \% 15, \% 20$ oranlarında katılarak güçlendirilen zemin karışımlarına proktor, serbest basınç, CBR deneyleri uygulanmış, AASHTO 1993 tasarım yöntemi yardımıyla esnek yol üst yapı kalınlığı tasarımı yapılmış ve üst yapı maliyetleri hesaplamıştır.

\section{Materyal ve Metot}

\subsection{Kullanılan Zemin}

Çalışmada yol taban zemini olarak kullanılan zemin malzemesi, İnönü Üniversitesi Yerleşkesi içerisinde bulunan bir sahadan temin edilmiştir. Deneylerde kullanılacak zemin örneğinin özelliklerinin tespit edilmesi amacıyla ASTM C136/ C136M uygun elek analizi ve ASTM D422-63'e göre hidrometre deneyi yapılarak, zemin içindeki tane boyutlarının dağılımı tespit edilmiştir. Tespit edilen granülometri eğrisi Şekil 1'de gösterilmiştir. 


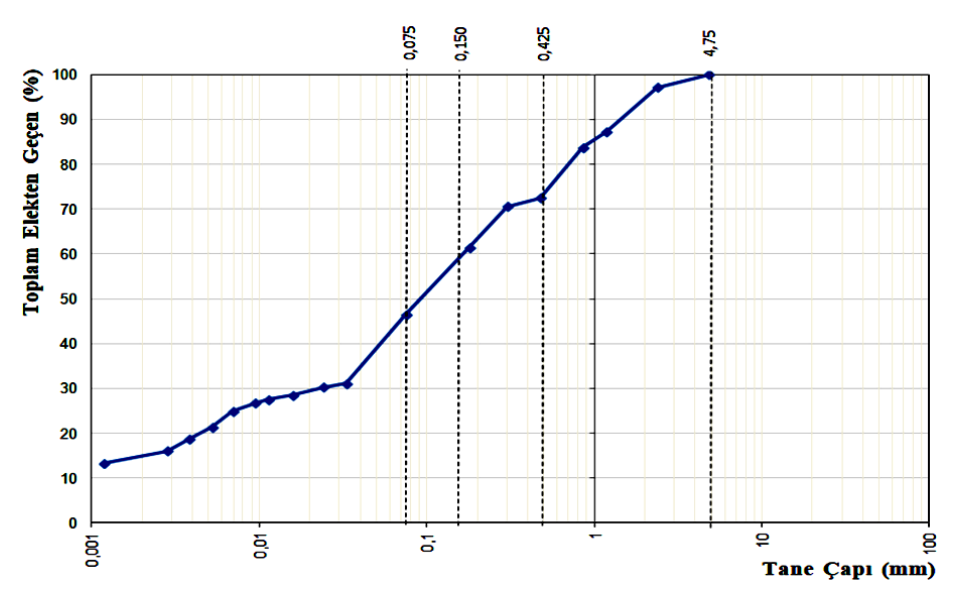

Şekil 1: Granülometri Eğrisi

Akabinde, zemin numunesinin kıvam limitleri (likit limit ve plastik limit) ASTM D4318 uygun tespit edilmiş ve özgül ağırlığının belirlenmesi maksadıyla ASTM D824 uygun olarak piknometre deneyi yapılmıştır. Daha sonra ASTM D698 standart proktor deneyi yardımıyla zeminin maksimum kuru birim hacim ağırlığ 1 ve optimum su muhteviyatı belirlenmiştir. Zemin örneğinin killi kum (SC) olduğu ve AASHTO sinıflandırma sistemine göre de zemin tipinin (A-6) olduğu tespit edilmiştir. Deneyler sonucu elde edilen zemin özellikleri Tablo 1'de gösterilmiştir.

Tablo 1: Zeminin Özellikleri

\begin{tabular}{|c|c|c|c|}
\hline Değişken Adı & Simge & Birim & Değeri \\
\hline Dane birim hacim ağırlı ̆̆ & $\gamma_{\mathrm{s}}$ & $\mathrm{g} / \mathrm{cm}^{3}$ & 2,714 \\
\hline Maksimum kuru birim hacim ağırlığı & $\gamma_{\mathrm{kmax}}$ & $\mathrm{g} / \mathrm{cm}^{3}$ & 1,948 \\
\hline Optimum su içeriği & $\mathrm{W}_{\mathrm{opt}}$ & $\%$ & 14,1 \\
\hline Likit limit & $\mathrm{W}_{\mathrm{L}}$ & $\%$ & 25,87 \\
\hline Plastik limit & $\mathrm{W}_{\mathrm{p}}$ & $\%$ & 14,56 \\
\hline Plastisite İndisi & PI & $\%$ & 11,31 \\
\hline Sınıflandırma (Birleştirilmiş Zemin Sınıfi) & - & - & $\mathrm{SC}$ \\
\hline AASTHO Sinıflandırması & - & - & A-6 \\
\hline
\end{tabular}

\subsection{Siyah Karbon}

$\mathrm{Bu}$ çalışmada katkı olarak, atık araç lastiklerinden elde edilen ve geri dönüşüm ürünlerinden biri olan siyah karbon kullanılmıştır. Siyah Karbon, karbon esaslı, siyah renkli, ince parçacıklardan oluşan, bir malzemedir. Bu malzeme, kullanım ömrünü tamamlamış araç lastiklerinden piroliz yöntemi ile elde edilen bir geri dönüşüm ürünüdür [12]. Tablo 2'de çalışmada kullanılan siyah karbon özellikleri gösterilmiştir.

Tablo 2. Çalışmada Kullanılan Siyah Karbon Özellikleri [12]

\begin{tabular}{ccc}
\hline \hline Değişken Adı & Birim & Değeri \\
\hline Görünüm & - & Toz \\
Renk & - & Siyah \\
Suda Çözünürlüğü $\left(20^{\circ} \mathrm{C}\right)$ & - & Çözülmez \\
Koku & - & Kokusuz \\
Erime noktası & ${ }^{\circ} \mathrm{C}$ & $>3000$ \\
Kaynama noktası & ${ }^{\circ} \mathrm{C}$ & $>3000$ \\
Dane birim hacim ağırlığ $\left(\gamma_{\mathrm{s}}\right)$ & $\mathrm{g} / \mathrm{cm}^{3}$ & $1,7-1,9$ \\
Kendiliğinden tutuşma sicaklığ1 & ${ }^{\circ} \mathrm{C}$ & $>140$ \\
& & $\mathrm{C} \% 56,73$ \\
Element Analizi & $\%$ & $\mathrm{H} \% 2,09$ \\
& & $\mathrm{~S} \% 2,11$ \\
& & $\mathrm{O} \% 39,07$
\end{tabular}

\subsection{Standart Proktor Deneyi}

Zeminin numunesindeki maksimum kuru birim hacim ağırlığının ve optimum su muhteviyatının belirlenmesi maksadıyla, zemin numunesindeki havanın, su ve mekanik araçlar vasıtasıyla dışarı atılması esasına dayanan standart proktor deneyi ASTM D698 uygun yapilır. Deneyde kullanılacak kalıbın ebatları (çap $105 \mathrm{~mm}$ ve $\mathrm{h}=115,5 \mathrm{~mm}$ ) 
ölçülür ve tartılarak ağırlığı kaydedilir. Daha sonra zemin numunesi etüvde kurutularak $\left(105{ }^{\circ} \mathrm{C}\right.$ 'de 24 saat) karar verilen oranlarda su eklenerek yoğrulur. Yoğrulan numuneler proktor kalıbına serilir ve sonra $2,5 \mathrm{~kg}$ ağırlığında tokmak ile $25 \mathrm{kez}$ vurulup sıkıştırılır. Serilme işlemi 3 kademede gerçekleştirilir, son tabaka serildikten sonra üst k1smı düzeltilir ve tartılır. Farklı su içeriklerinde bu işlem 5 defa tekrarlanır, her defasında su muhteviyatı ve kuru birim hacim ağırlığı hesaplanır. Hesaplanan değerler esas alınarak göre doygunluk eğrisi çizilir, maksimum kuru birim hacim ağırlık ve optimum su muhteviyatı değerleri belirlenir [13].

\subsection{Serbest Basınç Deneyi}

Kohezyonlu zeminlerde kayma mukavemetinin belirlenmesi maksadıyla uygulanan serbest basınç deneyi, ASTM D2166 standardına uygun yapılır. Deneyde eksenel gerilmenin en büyük değeri serbest basınç dayanımını (qu), drenajsız kayma mukavemeti ise; $\tau=\mathrm{cu}=\mathrm{qu} / 2$ bağıntısına göre hesaplanır. Deney uygulamasında, zemin numunesi etüvde kurutularak $\left(105{ }^{\circ} \mathrm{C}\right.$ 'de 24 saat) karar verilen oranlarda su eklenerek yoğrulur. Yoğrulan numuneler serbest basınç kalıbına serilir ve sonra tokmak ile $10 \mathrm{kez}$ vurulup sıkıştırılır. Serilme işlemi 4 kademede gerçekleştirilir ve son tabaka serildikten sonra kalıptan çıkarılır. Daha önceden belirlenen kür süresi için muhafaza edilir ve kür süresini tamamlayan numunelere deney uygulanır. Deney ekipmanındaki presin 100 $\mathrm{kN}$ dayanıma kadar yükleme yapması, deneyde dakikada \%0,52 arası birim boy kısalmasının olması, yapılan deneyin 10 dakikayı geçmemesi gerekir. Deney sonrasında deformasyon ve şekil değiştirmeler esas alınarak dayanım değerleri tespit edilir [13]. Şekil 2'de serbest basınç deneyi seti gösterilmiştir.
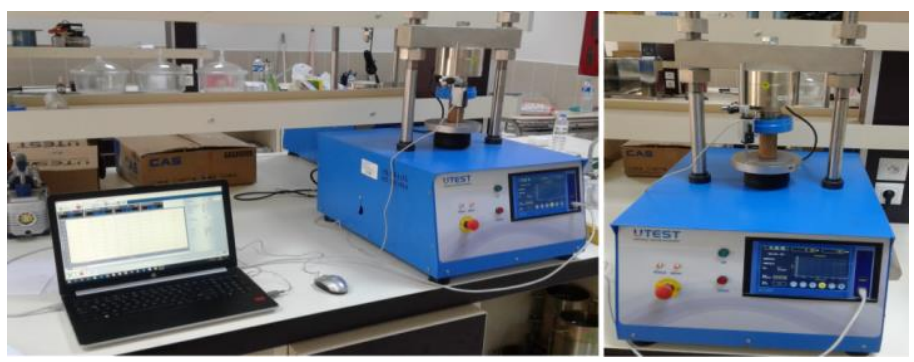

Şekil 2: Serbest Basınç Deneyi Seti

\subsection{Kaliforniya Taşıma Oranı (CBR) Deneyi}

CBR deneyi, daha önceden tespit edilen maksimum kuru birim hacim ağırlığı ve optimum su muhteviyatı esas alınarak hazırlanan numunelere, belirlenen kür süresinin ardından, alanı $1935 \mathrm{~mm}^{2}$ olan (çap1 $50 \mathrm{~mm}$ ) pistonun $1,27 \mathrm{~mm} / \mathrm{dk}$ hızla zemine itilmesi ile bulunan yük - penetrasyon bağlantısı vasıtasıyla taşıma gücünün hesaplanması esasına dayanır. Deney ASTM D1883-13 standardına uygun yapılır. Deney sonucunda bulunan CBR değeri; deneyde pistonun zemine 2,5 $\mathrm{mm}$ ve $5 \mathrm{~mm}$ penetrasyon yapması için uygulanan yük değerinin, pistonun standart kırma taş numunesine aynı derinlikte batması için uygulanan yük değerine bölünmesi ile

Tabaka kalınlıkları AASHTO (1993) Tasarım Rehberine göre Denklem (1) ile hesaplanmaktadır [14].

$\log \left(\mathrm{T}_{8.2}\right)=\mathrm{Z}_{\mathrm{R}} \times \mathrm{S}_{0}+9.36 \times \log (\mathrm{SN}+1)-0.20+\frac{\log \left(\frac{\Delta \mathrm{PSI}}{4.2-1.5}\right)}{0.40+\frac{1094}{(\mathrm{SN}+1)^{5.19}}}+2.32 \times \log \mathrm{M}_{\mathrm{R}}-8.07$ bulunan sonucun yüzde ifadesidir. CBR deneyinin uygulamasında, ilk önce kullanılacak kalıbın ebatları (çap 150 $\mathrm{mm}$ ve $\mathrm{h}=127,3 \mathrm{~mm}$ ) kontrol edilir ve kaydedilir. Daha sonra, kullanılacak zemin numunesi etüvde $105{ }^{\circ} \mathrm{C}$ 'de 24 saat kurutulur ve optimum su muhteviyatı esas alınarak zemin numunesi hazırlanır. Hazırlanan zemin numunesi CBR kalıbına 3 kademede serilir ve her tabaka serildikten sonra $2,5 \mathrm{~kg}$ ağırlığında tokmak ile $56 \mathrm{kez}$ vurulup sıkıştırılır. Son tabaka serildikten kalıp ile numune birlikte tartılır. Planlanan kür süresini tamamlaması için muhafaza edilir ve kür süresini tamamlayan numuneler deney setine yerleştirilir. Deney sonucunda $2,5 \mathrm{~mm}$ ve $5 \mathrm{~mm}$ penetrasyon için CBR değerleri belirlenir [13]. Şekil 3'de CBR deney seti gösterilmiştir.

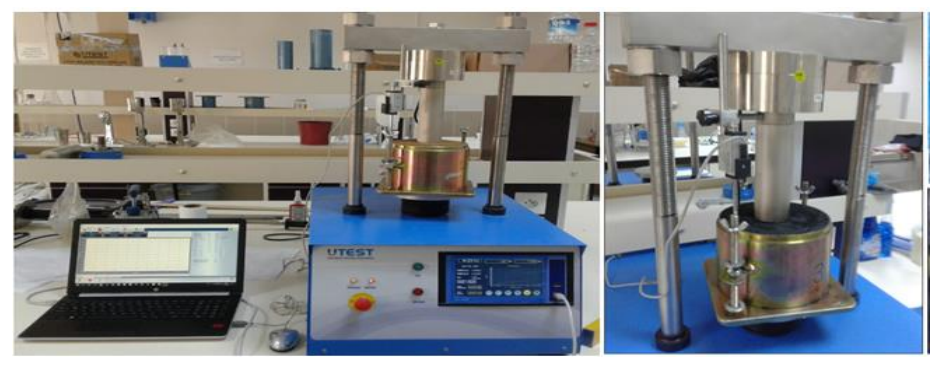

Şekil 3: CBR Deneyi Seti

\subsection{AASHTO Metodu ile Esnek Üst Yapısı Tasarımı}

Karayolu esnek üstyapısı tasarımında, bağlayıcı olarak asfalt çimentosu kullanılmaktadır. Genel olarak asfalt betonu kaplama, temel ve alttemel tabakalarından oluşmaktadır. Tasarımda proje ömrü ve tabaka kalınlıkları belirlenirken; zemin durumu, trafik, bölgesel ve ekonomik faktörler göz önüne alınır [14]. Şekil 4'de esnek üstyapıyı oluşturan tabakalar gösterilmiştir.

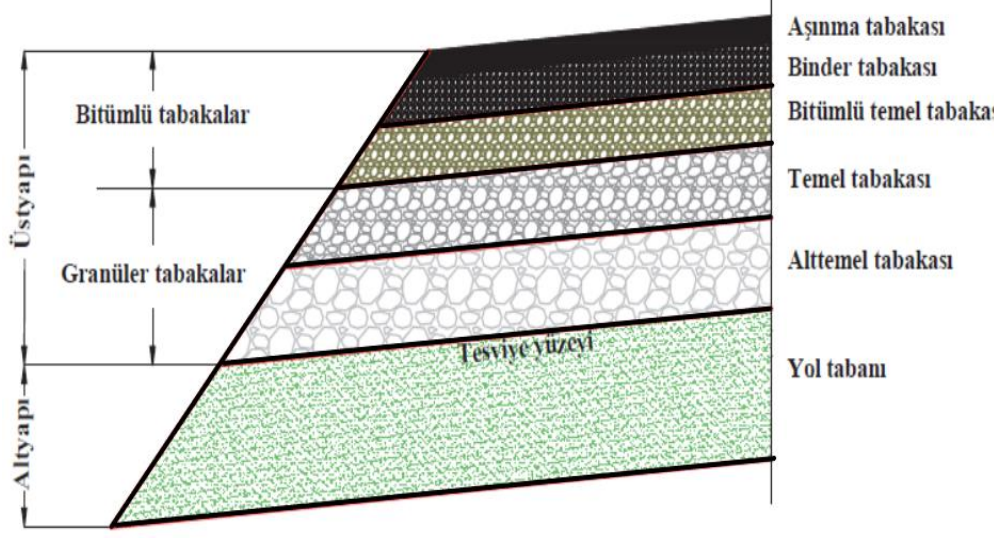

Şekil 4: Esnek Üstyapı Kesit Görünümü [15]

Burada; 
$\mathrm{T}_{8,2}: 8,2$ ton eşdeğer standart tek dingil yükü tekrar sayısı (proje trafiği),

$\mathrm{M}_{\mathrm{R}}$ Taban zemini efektif elastisite modülü (psi),

$\mathrm{S}_{0}$ : Trafik tahmini ve performans tahmininin bileşik standart hatası,

$\mathrm{Z}_{\mathrm{R}}$ : Standart sapma,

SN: Üstyapı kalınlığını bulmak için gerekli üstyapı sayısı,

$\mathrm{P}_{0}$ : Başlangı̨̧ servis kabiliyeti indeksi,

$\mathrm{P}_{\mathrm{t}}$ : Nihai servis kabiliyeti indeksi,

$\Delta$ PSI: Toplam servis yeteneği kaybını göstermektedir.

SN değeri Denklem 1 ile tespit edilmekten sonra tabaka katsayıları Tablo 3'e göre alınarak esnek üstyapı tabaka kalınlıkları Denklem 2 ile hesaplanmaktadır [14] .

$\mathrm{SN}=\mathrm{a}_{1} \times \mathrm{D}_{1}+\mathrm{a}_{2} \times \mathrm{D}_{2} \times \mathrm{M}_{2}+\mathrm{a}_{3} \times \mathrm{D}_{3} \times \mathrm{M}_{3}$ $. a_{\mathrm{i}} \times \mathrm{D}_{\mathrm{i}}$

Bu denklemde; $\mathrm{D}_{1}, \mathrm{D}_{2}, \mathrm{D}_{3}$ kaplama, temel, alttemel tabaka kalınlıkları, $a_{1}, a_{2}, a_{3}$ kaplama, temel ve alttemel tabakalarının izafi mukavemet katsayılarını; $\mathbf{M}_{2}, \mathrm{M}_{3}$ ise temel ve alttemel

Tablo 3: Esnek Üstyapı İçin Tabaka Katsayıları [14]

\begin{tabular}{|c|c|c|c|}
\hline Tabaka Cinsi & Marshall Stabilitesi (kg) & $\mathrm{CBR}(\%)$ & $\begin{array}{c}\text { İzafi Mukavemet Katsayıs } \\
\text { (a) }\end{array}$ \\
\hline \multicolumn{4}{|l|}{ Kaplama Tabakası } \\
\hline Aşınma & $\geq 900$ & - & 0,42 \\
\hline Binder & $\geq 750$ & - & 0,40 \\
\hline Bitümlü Temel & $\geq 600$ & - & 0,36 \\
\hline \multicolumn{4}{|l|}{ Temel Tabakası } \\
\hline Granüler Temel & - & $\geq 100$ & 0,14 \\
\hline Plentmiks Temel & - & $\geq 120$ & 0,15 \\
\hline \multicolumn{4}{|l|}{ Alttemel Tabakası } \\
\hline Kum-Çakıl Alttemel & - & $\geq 30$ & 0,11 \\
\hline Kırmataş Alttemel & - & $\geq 50$ & 0,13 \\
\hline
\end{tabular}

Esnek üstyapı tabaka kalınlıkları tespit edildikten sonra Şekil 5'de verilen $\mathrm{SN}^{*}$ değerleri hesaplanarak tabaka

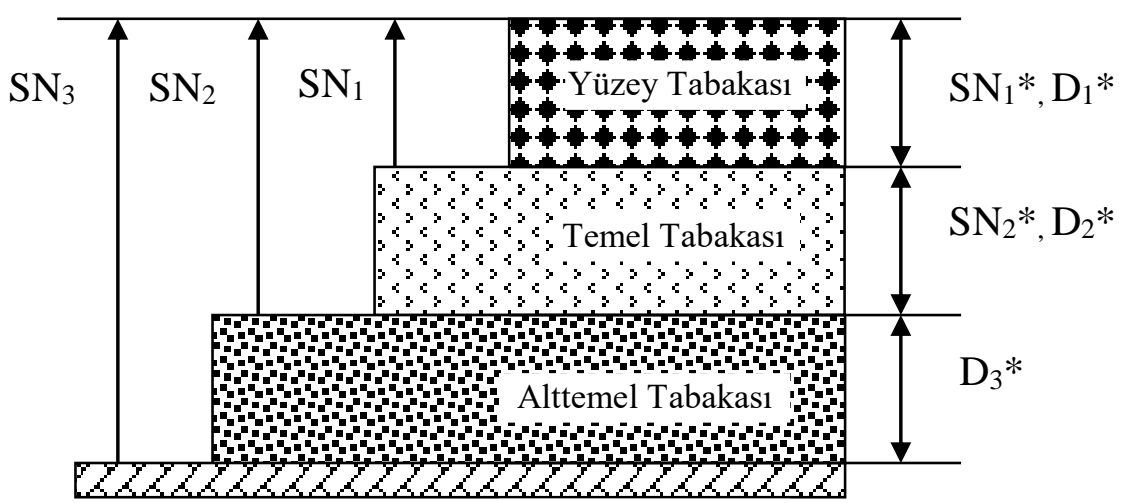

Taban Zemini

Şekil 5: Esnek Ustyapıda Ustyapı Sayıları [16]

Şekilde;

$\mathrm{SN}_{1}$ : Temel tabakası üzerine gereken $\mathrm{SN}$,

$\mathrm{SN}_{2}$ : Alttemel tabakası üzerine gereken $\mathrm{SN}$,

$\mathrm{SN}_{3}$ : Taban üzerine gereken $\mathrm{SN}$,

* : Kullanılan malzemeye göre mevcut değerleri göstermektedir [16]. 


\section{Bulgular ve Değerlendirme}

Yol taban zemininin siyah karbon ile stabilizasyonunun esnek yol üst yapısı kalınlık ve maliyetine etkisinin araştırıldığı bu çalışmada, ilk olarak zemin numunesine elek analizi, hidrometre deneyi, kıvam limitleri deneyleri, piknometre deneyi yapılmıştır. Akabinde, saf zemin ve ağırlıkça \%2,5; \%5, $\% 10, \% 15, \% 20$ oranlarında siyah karbon ile güçlendirilen numunelere standart proktor deneyi, 1 ve 7 gün kür süresinin ardından serbest basınç deneyi uygulanmıştır. Serbest basınç deneyi ile belirlenen optimum karışım oranına (\%10C) göre 1 ve 7 gün kür süresinin ardından $C B R$ deneyleri yapılmıştır. Bulunan CBR deneyleri sonuçlarına göre; saf zemin ve siyah karbon katkılı zemin için AASHTO 1993 tasarım yöntemi esas alınarak esnek yol üst yapı kalınlığı tasarımı yapılmış ve üst yapı maliyetleri hesaplamıştır

\subsection{Standart Proktor Deneyi Bulguları}

Saf zemin ve $\% 2,5 ; \% 5, \% 10, \% 15$ ve $\% 20$ siyah karbon (C) ilaveli numuneler, standart proktor deneyine tabi tutulmuştur. Deney neticesinde; optimum su içerikleri (\%w) ve maksimum kuru birim hacim ağırlıkları $\left(\gamma_{\mathrm{kmax}}\right)$ tespit edilmiştir. Deney sonucunda hesaplanan değerlere göre çizilen kompaksiyon eğrileri Şekil 6'da ve Tablo 4'de deney sonuçları gösterilmiştir.

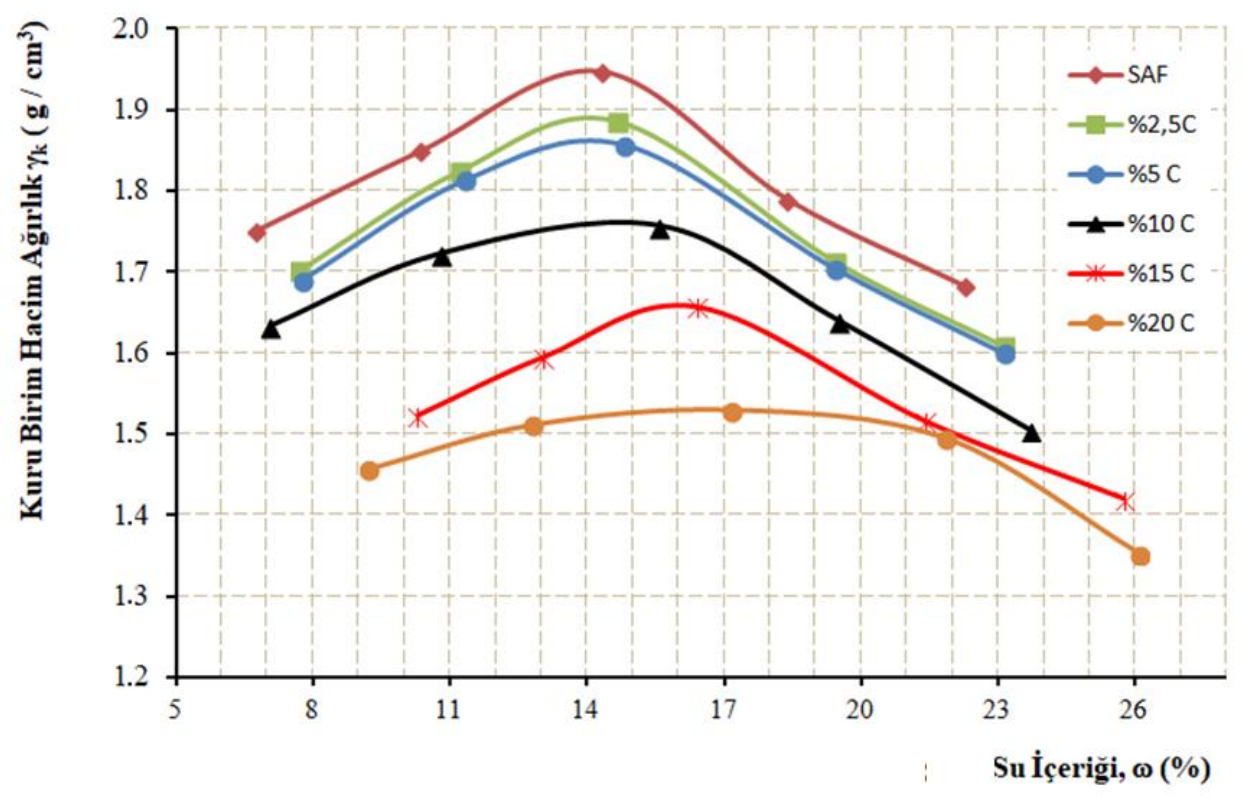

Şekil 6: Standart Proktor Deneyi Kompaksiyon Eğrisi

Tablo 4: Standart Proktor Deneyi Sonuçları

\begin{tabular}{ccc}
\hline \hline Test Numunesi & $\begin{array}{c}\text { Maksimum Kuru Birim Hacim Ağırlığı } \\
\gamma_{\mathrm{k}}\left(\mathrm{g} / \mathrm{cm}^{3}\right)\end{array}$ & \begin{tabular}{c} 
Optimum Su İçeriği \%w \\
\hline Saf Zemin
\end{tabular} \\
\hline Saf Zemin+ \%2,5 C & 1,948 & 14,10 \\
Saf Zemin+ \%5 C & 1,893 & 14,14 \\
Saf Zemin+ \%10 C & 1,862 & 14,20 \\
Saf Zemin+ \%15 C & 1,762 & 14,90 \\
Saf Zemin+ \%20 C & 1,658 & 15,85 \\
\hline
\end{tabular}

Katk1 malzemesi olarak kullanılan siyah karbon, tanecikli ve boşluklu bir zincir yapısına sahiptir [17]. Deney sonucunda; siyah karbon oranı artıkça \%w değerinin arttığı, $\gamma \mathrm{k}$ değerinin azaldığı görülmüştür, bu durumun siyah karbonun boşluklu yapısının karışımın absorbe kapasitesini arttırması nedeniyle meydana geldiği düşünülmektedir. Bu sonucun literatür [10] ile farklılık göstermediği de tespit edilmiştir.

\subsection{Serbest Basınç Deney Bulguları}

Serbest basınç deneyinde, saf zemin ve $\% 2,5 ; \% 5, \% 10$, $\% 15$ ve \%20 siyah karbon ilaveli numuneler, standart proktor deneyinde tespit edilen $\% \mathrm{w}$ ve $\gamma_{\mathrm{k}}$ değerleri esas alınarak hazırlanmıştır. Numuneler 1 ve 7 gün kür süresinin ardından serbest basınç deneyine tabi tutulmuştur. Numunelerin tespit edilen serbest basınç mukavemeti (q) ve birim şekil değiştirme
(ع) değerleri grafikleri Şekil 7 ve 8 'de, elde edilen $q-\varepsilon$ değerleri Tablo 5 ve 6 'da verilmiştir. 


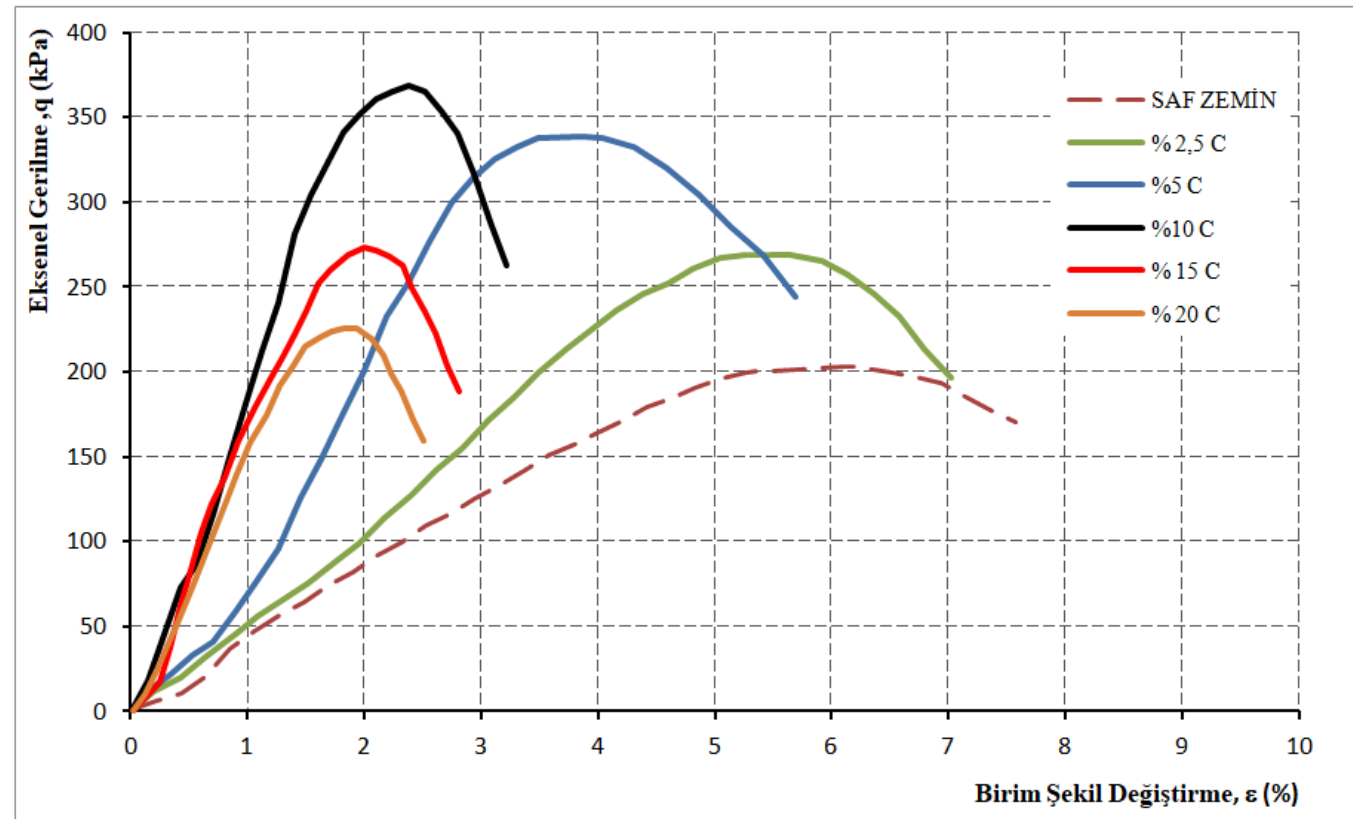

Şekil 7: 1 Günlük Kür Sonrası Serbest Basınç Deneyinden Elde Edilen q- $\varepsilon$ Grafiği

Tablo 5: 1 Günlük Kür Sonrası Serbest Basınç Deneyinden Elde Edilen q- $\varepsilon$ Değerleri

\begin{tabular}{ccc}
\hline \hline \multirow{2}{*}{ Test Numunesi } & $\begin{array}{c}\text { Serbest Basinç Mukavemeti } \\
\text { q(kpa) }\end{array}$ & Birim Şekil Değiştirme $\varepsilon(\%)$ \\
\hline Saf Zemin & 202,81 & 6,21 \\
Saf Zemin+ \%2,5 C & 268,85 & 5,65 \\
Saf Zemin+ \%5 C & 338,70 & 3,86 \\
Saf Zemin+ \%10 C & 368,49 & 2,38 \\
Saf Zemin+ \%15 C & 273,50 & 2,01 \\
Saf Zemin+ \%20 C & 225,52 & 1,94 \\
\hline
\end{tabular}

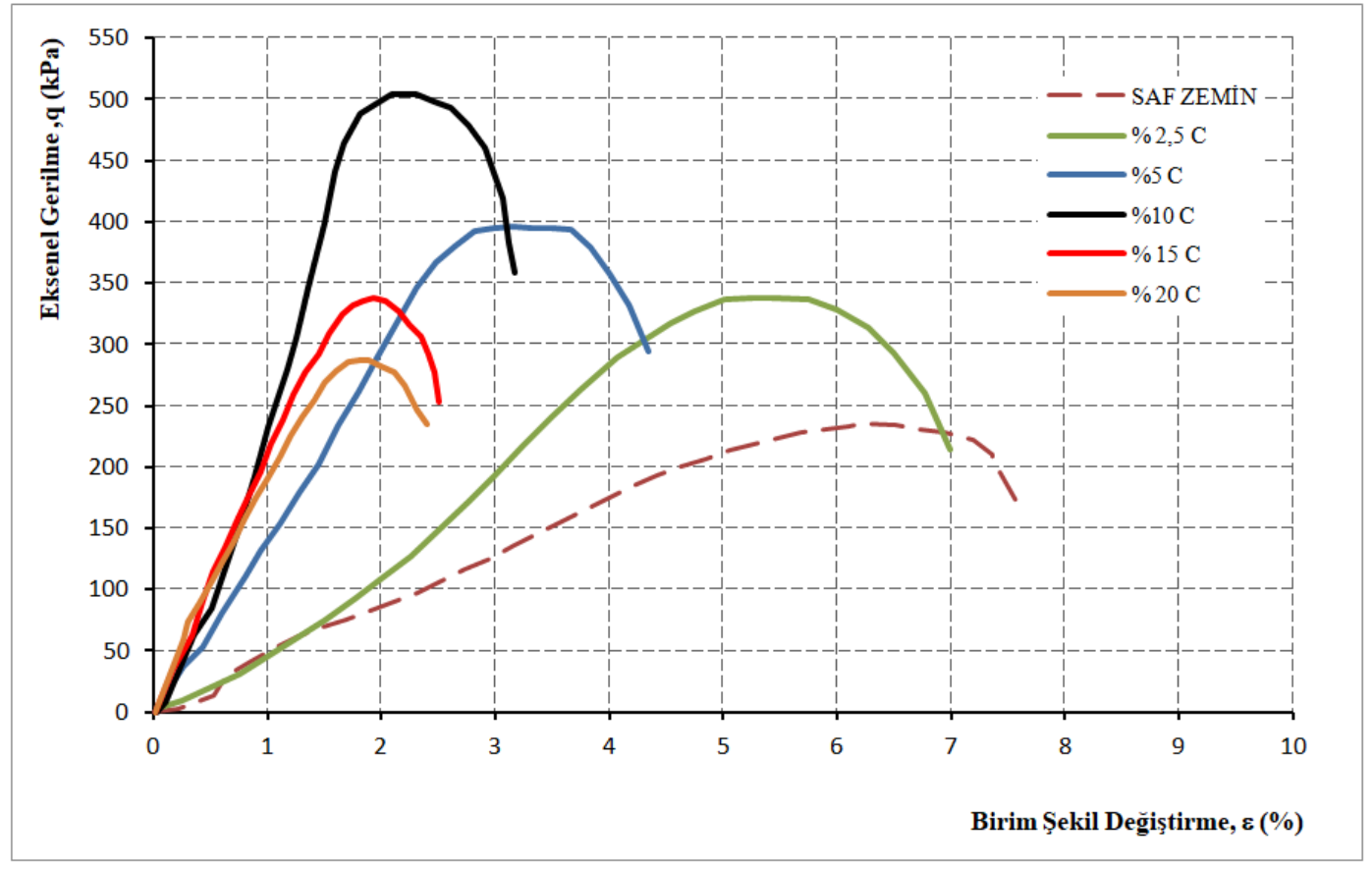

Şekil 8: 7 Günlük Kür Sonrası Serbest Basınç Deneyinden Elde Edilen q-e Grafiği 
Tablo 6: 7 Günlük Kür Sonrası Serbest Basınç Deneyinden Elde Edilen q- $\varepsilon$ Değerleri

\begin{tabular}{ccc}
\hline \hline \multirow{2}{*}{ Test Numunesi } & $\begin{array}{c}\text { Serbest Basıç Mukavemeti } \\
\text { q (kpa) }\end{array}$ & $\begin{array}{c}\text { Birim Şekil Değiştirme } \\
\varepsilon(\%)\end{array}$ \\
\hline Saf Zemin & 235,43 & 6,1 \\
Saf Zemin+ \%2,5 C & 337,38 & 5,42 \\
Saf Zemin+ \%5 C & 393,40 & 3,66 \\
Saf Zemin+ \%10 C & $\mathbf{5 0 4 , 0 2}$ & $\mathbf{2 , 0 8}$ \\
Saf Zemin+ \%15 C & 335,41 & 1,93 \\
Saf Zemin+ \%20 C & 286,74 & 1,89 \\
\hline
\end{tabular}

Serbest basıç deneyi sonuçları incelendiğinde; saf zeminin serbest basınç mukavemet değerinin, siyah karbon ile stabilize edilmesi ile arttırdığı görülmüştür. Siyah karbon ile güçlendirilen zeminlerde en büyük mukavemet değeri 1 ve 7 günlük kür sonunda $\% 10 \quad \mathrm{C}$ ilaveli numunelerde tespit edilmiştir. Saf zemine göre mukavemet değerin 1 ve 7 günlük kür sonunda sırasıyla 1,82 ve 2,14 kat arttığı görülmüştür. Mukavemetteki bu önemli artış, siyah karbonun zeminlerin kohezyon kuvveti ve kayma direnci üzerinde önemli bir etkiye sahip olduğunu göstermektedir. Ayrıca, optimum karışım miktarının \%10C ile sınırlı kalmasının, literatürde [18-19]; siyah karbon katılan bileşimlerin sertliğinin artması sebebiyle, ilave edilen siyah karbon miktarının belirli bir limiti aşmaması gerektiği [18] ve malzeme sertliğinin siyah karbon ilavesiyle lineer olarak arttığ ancak, gerilme direncinin belirli bir miktardan sonra azaldığ1 [19] görüşü ile örtüştüğü görülmektedir.

\subsection{Kaliforniya Taşıma Oranı (CBR) Deneyine ait Bulgular}

CBR deneyi için, serbest basınç deneyleri sonuçları incelenerek optimum siyah karbon miktarı \%10 olarak tespit edilmiş, saf zemin ve $\% 10$ karbon ilaveli zemin numuneleri optimum su içerikleri ve maksimum kuru birim hacim ağırlığ göz önüne alınarak hazırlanmıştır. Hazırlanan numuneler 1 ve 7 günlük kür sürecinin ardından CBR deneyi uygulanmıştır. CBR deneyi sonucu elde edilen yük-deplasman grafikleri 1 ve 7 günlük kür süreleri için sırasıyla Şekil 9 ve 10'da; tespit edilen CBR değerleri ise Tablo 7 ve 8 'de gösterilmiştir.

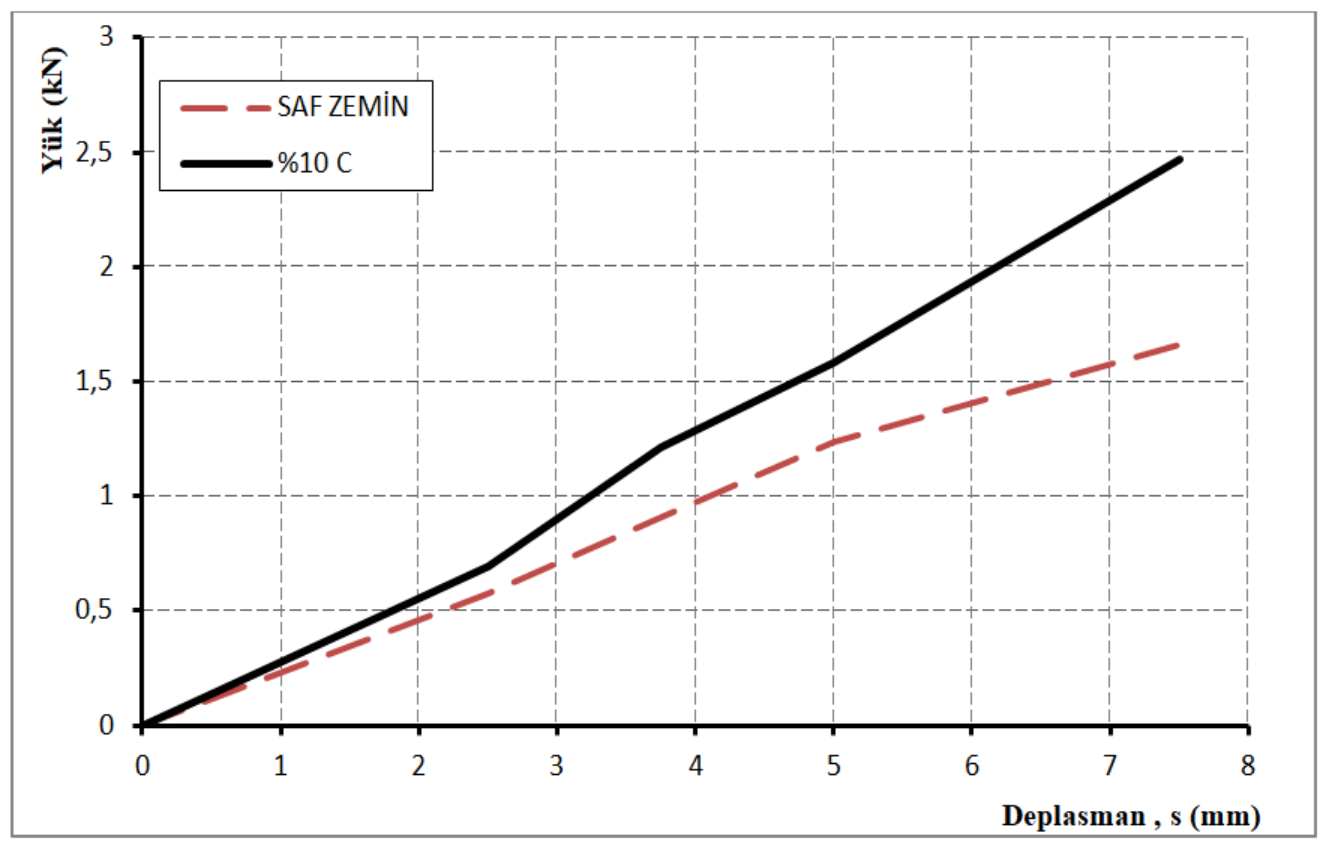

Şekil 9: 1 Günlük Kür Sonrası CBR Deneyinden Elde Edilen Yük-Deplasman Verileri

Tablo 7: 1 Günlük Kür Sonrası Elde Edilen CBR Değerleri

\begin{tabular}{ccc}
\hline \hline Test Numunesi & $\begin{array}{c}2,5 \mathrm{~mm} \text { için CBR Değeri, } \\
(\%)\end{array}$ & $\begin{array}{c}5 \mathrm{~mm} \text { için CBR Değeri, } \\
(\%)\end{array}$ \\
\hline Saf Zemin & 4,32 & 6,21 \\
Saf Zemin+\%10C & 5,24 & 7,92 \\
\hline
\end{tabular}

Şekil 9 ve Tablo 7'deki CBR deneyi sonuçları incelendiğinde, 1 günlük kür süresi tabi tutulan numunelerde 2,5 ve $5 \mathrm{~mm}$ 'lik deplasmanlara tekabül eden CBR verileri sırası ile katkısız zemin için \%4,32 ve \%6,21, \%10 siyah karbon ilaveli zemin için \%5,24 ve \%7,92 olarak elde edilmiştir. CBR değerinin, siyah karbon ilaveli numunelerde $2,5 \mathrm{~mm}-5 \mathrm{~mm}$ penetrasyon için, saf numunelere kıyasla sırasıyla 1,21 ve 1,28 kat arttığı tespit edilmiştir. 


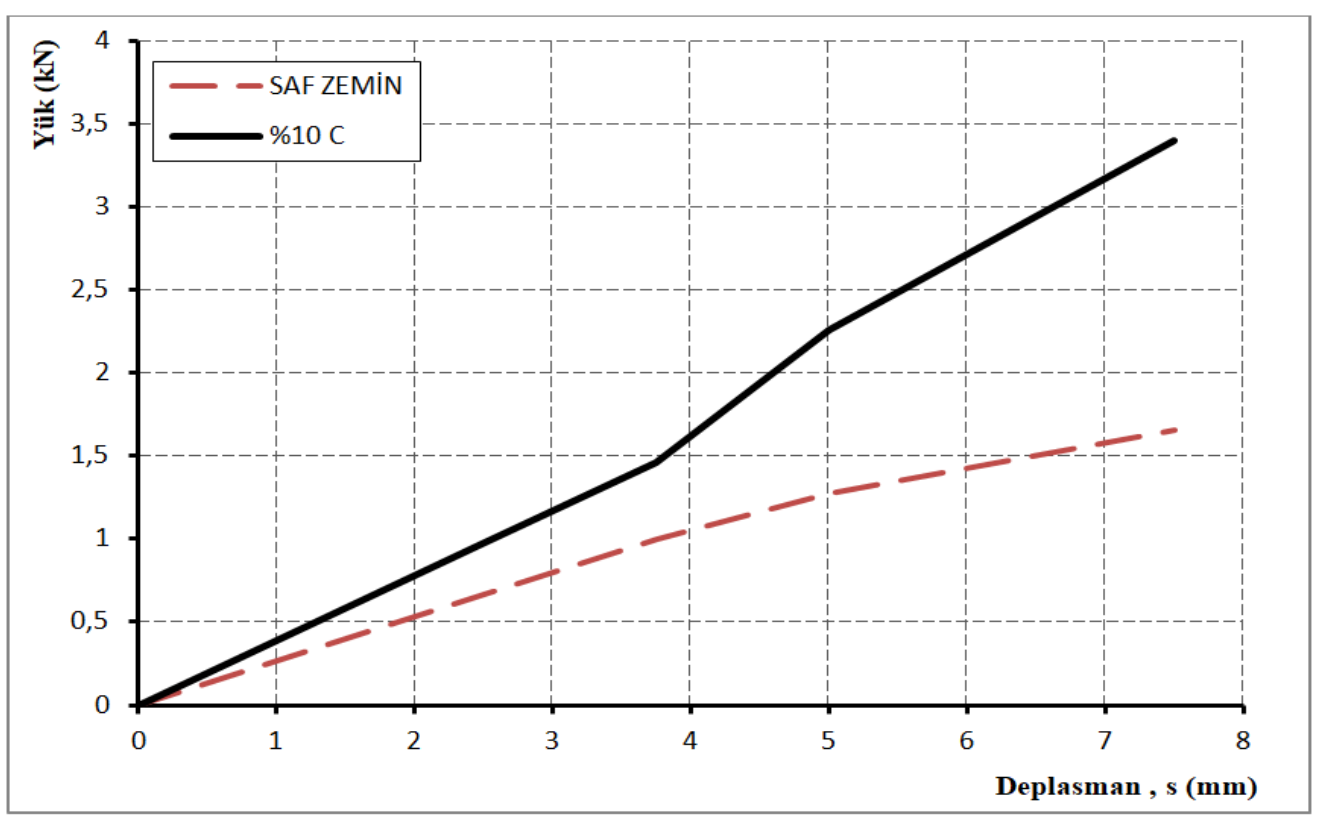

Şekil 10: 7 Günlük Kür Sonrası CBR Deneyinden Elde Edilen Yük-Deplasman Verileri

Tablo 8: 7 Günlük Kür Sonrası Elde Edilen CBR Değerleri

\begin{tabular}{ccc}
\hline \hline Test Numunesi & $\begin{array}{c}2,5 \mathrm{~mm} \text { için CBR Değeri, } \\
(\%)\end{array}$ & $\begin{array}{c}5 \mathrm{~mm} \text { için CBR Değeri, } \\
(\%)\end{array}$ \\
\hline Saf Zemin & 5,02 & 6,38
\end{tabular}

Saf Zemin+\%10C 7,40

Şekil 10 ve Tablo 8'deki CBR deneyi sonuçları incelendiğinde; 7 günlük kür süresi tabi tutulan numunelerde 2,5 ve 5 mm'lik deplasmanlara tekabül eden CBR değerleri saf zemin için \%5,02 ve \%6,38; \%10 C ilaveli zemin için \%7,40 ve $\% 11,32$ olarak elde edilmiştir. CBR değerinin, siyah karbon ilaveli numunelerde $2,5 \mathrm{~mm}$ - $5 \mathrm{~mm}$ penetrasyon için, saf numunelere kıyasla sirasiyla 1,47 ve 1,77 kat arttığ 1 tespit edilmiştir. Literatürde [10], siyah karbonun ilave edildiği karışımların CBR değerinin, saf numunenin CBR değerinden fazla olduğu belirtilmiştir. 1 ve 7 günlük kür sonucu bulunan CBR değerlerinin literatürü desteklediği görülmektedir.

\subsection{AASHTO Metodu ile Esnek Üst Yapısı Tasarımı Yapılması}

AASHTO 1993 Tasarım Rehberi esas alınarak, 1 ve 7 günlük kür süresi sonunda elde edilen en büyük CBR değerleri kullanılarak üstyapı tasarımı yapılmıştır. Yapılan hesaplamalarda 1 günlük kür süresi sonunda belirlenen CBR değerlerinden; saf zemin için \%6,21 ve \% 10C katk1lı numune için \%7,92 değerleri esas alınarak hesaplamalar yapılmıştır. Bunun için öncelikle yol taban zeminin esneklik modülü $\left(\mathrm{M}_{\mathrm{R}}\right)$ hesaplanmıştır.
11,32

Zemine ait $M_{R}$ ve CBR değerleri arasında $M_{R}=1500 \times C B R$ bağıntısı mevcut olup, zemine ait $\mathrm{CBR}$ değerinin bilinmesi durumunda $M_{R}$ değeri yaklaşık olarak hesaplanabilmektedir [20]. Yapılan hesaplamalara $M_{R}$ değerlerine göre saf zemin için 9.315 psi (64241379 Pa) ve \%10C katkılı numune için 11.880 psi (81931035Pa) olarak bulunmuştur. Tablo 9'daki ortak değerler kullanılarak Denklem 1 yardımı ile saf zemin ve \% 10 $\mathrm{C}$ ilaveli zeminler için taban üzerine gereken $\mathrm{SN}_{3}$ (taban üzerine gereken SN) değerleri sırasıyla 5,67 inç $(14,40 \mathrm{~cm})$ ve 5,26 inç $(13,36 \mathrm{~cm})$ olarak hesaplanmıştır.

Aynı şekilde, 7 günlük kür süresi sonunda belirlenen CBR değerlerinden yapılan hesaplamalarda; saf zemin için $\% 6,38$ ve $\%$ 10C ilave edilen numune için \%11,32 CBR değerleri esas alınarak hesaplamalar yapılmıştır. Bunun için öncelikle yol taban zeminin esneklik modülü $\left(\mathrm{M}_{\mathrm{R}}\right)$ hesaplanmıştır.

Yapılan hesaplamalara $M_{R}$ değerleri, saf zeminin için 9.570 psi $(66000000 \mathrm{~Pa})$ ve \%10C ilave edilen numune için $16.980 \mathrm{psi}$ (117103448 Pa) olarak bulunmuştur. Tablo 9'daki ortak değerler kullanılarak Denklem 1 yardımı ile saf zemin ve \% $10 \mathrm{C}$ ilaveli zeminler için taban üzerine gereken $\mathrm{SN}_{3}$ değerleri sırasıyla 5,63 inç $(14,30 \mathrm{~cm})$ ve 4,67 inç $(11,86 \mathrm{~cm})$ olarak hesaplanmıştır. 
Tablo 9: Esnek Kaplama Hesabinda Kullanılan Parametreler

\begin{tabular}{lc}
\hline \hline \multicolumn{1}{c}{ Parametreler } & Seçilen Değerler \\
\hline Eşdeğer standart dingil yükü tekerrür sayısı, $\mathrm{T}_{8,2}$ & 30.000 .000 \\
Toplam standart sapma, $\mathrm{S}_{0}$ & 0,45 \\
Yolun ilk servis kabiliyeti, $\mathrm{P}_{0}$ & 4,2 \\
Yolun son servis kabiliyeti, Pt (Otoyollar, devlet yolları için 2,5) & 2,5 \\
Servis kabiliyeti indeksi, $\Delta$ PSI & 1,7 \\
Güvenilirliğin standart normal sapması, $\mathrm{Z}_{\mathrm{R}}(\mathrm{R}=\% 95)$ & $-1,645$ \\
\hline
\end{tabular}

\subsubsection{Esnek Üstyapı Tabaka Kalınlıklarının Belirlenmesi}

Denklem 1 bağıntısı ile 1 günlük kür uygulanan saf ve \%10C katkılı zeminler için $\mathrm{SN}_{3}$ değerleri esas alınarak esnek

Tablo 10: 1 Günlük Kür Uygulanan Saf Zemin için Seçilen Tabaka Kalınlıkları

\begin{tabular}{ccccc}
\hline \hline Tabaka Adı & Kalınlık (Di); $(\mathrm{cm})$ & $\begin{array}{c}\text { İzafi Mukavemet } \\
\text { Katsayısı (ai) }\end{array}$ & SN*= ai x Di & Açıklamalar \\
\hline Aşınma & 5 & 0,42 & 2,1 & SN*>SN \\
Binder & 8 & 0,4 & 3,2 & $(14,47>14,40)$ \\
Bitümlü Temel & 12 & 0,36 & 4,32 & Seçilen tabaka \\
Plent-miks Temel & 15 & 0,15 & 2,25 & kalınlıkları \\
Kıygundur.
\end{tabular}

SN* üst yapıda kullanılan gerçek değerler kullanılarak bulunan değer, SN bağıntı (1) hesaplanandır.

Tablo 11: 1 Günlük Kür Uygulanan \%10C Katkılı Zemin için Seçilen Tabaka Kalınlıkları

\begin{tabular}{ccccc}
\hline \hline Tabaka Adı & Kalınlık (Di); $(\mathrm{cm})$ & $\begin{array}{c}\text { İzafi Mukavemet } \\
\text { Katsayısı (ai) }\end{array}$ & SN*=ai x Di & Açıklamalar \\
\hline Aşınma & 5 & 0,42 & 2,1 & SN*>SN \\
Binder & 8 & 0,4 & 3,2 & $(13,46>13,36)$ \\
Bitümlü Temel & 11 & 0,36 & 3,96 & Seçilen tabaka \\
kalınlıkları \\
Plent-miks Temel
\end{tabular}

SN* üst yapıda kullanılan gerçek değerler kullanılarak bulunan değer, SN bağıntı (1) hesaplanandır.
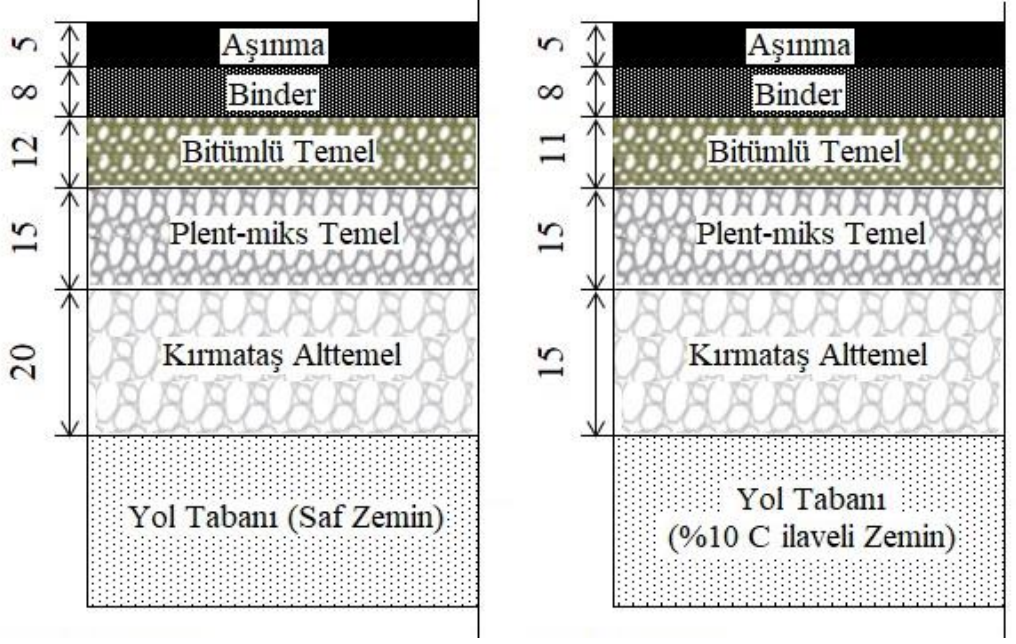

Şekil 11: 1 Günlük Kür Uygulanan Saf ve \%10C Katkılı Zemin için Seçilen Tabaka Kalınlıkları

Seçilen tabaka kalınlıklarının kontrolünün yapılabilmesi maksadıyla, Tablo 3'den plentmix kırmataş temel için $\mathrm{CBR}=120$ ve kırmataş alt temel için $\mathrm{CBR}=50$ seçilerek, plentmix kırmataş temel için $\mathrm{M}_{\mathrm{R}}=180.000$ psi ve alt temel için $\mathrm{M}_{\mathrm{R}}=75.000 \mathrm{psi}$ olarak hesaplanır. $M_{R}$ değeri hesaplandıktan sonra, bu tabakalar üstünde gerekli SN değerleri Denklem 1 bağıntı yardımı ile plentmix kırmataş temel için $\mathrm{SN}_{1}=1,91$ inç $(4,85 \mathrm{~cm})$, kırmataş alt temel için $\mathrm{SN}_{2}=2,69$ inç $(6,83 \mathrm{~cm})$ olarak hesaplanmıştır. 
Denklem 2'de, izafi mukavemet katsayıları ve tabaka kalınlıkları kullanılarak yapılan kontrolde, saf zeminlerde, kırmataş temel için 9,62 > 4,85 ve kırmataş alttemel için 11,87 >6,83 olduğu, benzer şekilde \%10C içeren zeminler kırmataş temel için 9,26> 4,85 ve kırmataş alttemel için 11,51 >6,83 olduğu için esnek tabaka kalınlıklarının yeterli olduğu görülmüştür.

Saf ve \%10C katkılı zemin için belirlenen üstyapı tabaka kalınlıkları toplamı sirasıyla $60 \mathrm{~cm}$ ve $54 \mathrm{~cm}$ olarak belirlenmiştir. Yapılan hesaplamada; \%10C içeren zeminler için üstyapı kalınlığında saf zemine kıyasla \%10 oranında azalma olduğu tespit edilmiştir.

Denklem 1 bağıntısı ile 7 günlük kür uygulanan saf ve \%10C katkılı zeminler için $\mathrm{SN}_{3}$ değerleri esas alınarak esnek üstyapı tabaka kalınlıkları seçilmiş ve bu kalınlıklar sırasıyla Tablo 12 ve 13'de verilmiştir. Ayrıca, seçilen esnek üstyapı tabaka kalınlıkları Şekil 12'de gösterilmiştir.

Tablo 12: 7 Günlük Kür Uygulanan Saf Zemin için Seçilen Tabaka Kalınlıkları

\begin{tabular}{ccccc}
\hline \hline Tabaka Adı & $\begin{array}{c}\text { Kalınlık (Di); } \\
(\mathrm{cm})\end{array}$ & $\begin{array}{c}\text { İzafi Mukavemet } \\
\text { Katsayısı (ai) }\end{array}$ & SN*= ai x Di & Açıklamalar \\
\hline Aşınma & 5 & 0,42 & 2,1 & $\mathrm{SN}^{*}>\mathrm{SN}$ \\
Binder & 8 & 0,4 & 3,2 & $(14,34>14,30)$ \\
Bitümlü Temel & 12 & 0,36 & 4,32 & $\begin{array}{c}\text { Seçilen tabaka } \\
\text { kalınlıkları } \\
\text { uygundur. }\end{array}$ \\
Plent-miks Temel & 15 & 0,15 & 2,25 & 2,47 \\
\hline
\end{tabular}

SN* üst yapıda kullanılan gerçek değerler kullanılarak bulunan değer, SN bağıntı (1) hesaplanandır.

Tablo 13: 7 Günlük Kür Uygulanan \%10C İlaveli Zemin için Seçilen Tabaka Kalınlıkları

\begin{tabular}{ccccc}
\hline \hline Tabaka Adı & $\begin{array}{c}\text { Kalınlık (Di); } \\
(\mathrm{cm})\end{array}$ & $\begin{array}{c}\text { İzafi Mukavemet } \\
\text { Katsayısı (ai) }\end{array}$ & SN*= ai x Di & Açılkamalar \\
\hline Aşınma & 5 & 0,42 & 2,1 & SN*>SN \\
Binder & 7 & 0,4 & 2,8 & $(11,98>11,86)$ \\
Bitümlü Temel & 8 & 0,36 & 2,88 & $\begin{array}{c}\text { Seçilen tabaka } \\
\text { kalınlıkları }\end{array}$ \\
Plent-miks Temel & 15 & 0,15 & 2,25 & uygundur. \\
Kirmataş Alttemel & 15 & 0,13 & 1,95 & \\
\hline
\end{tabular}

SN* üst yapıda kullanılan gerçek değerler kullanılarak bulunan değer, SN bağıntı (1) hesaplanandır.

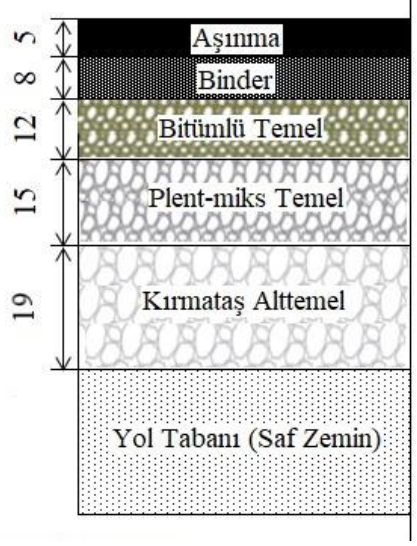

Şekil 12: 7 Günlük Kür Uygulanan Saf ve \%10C İ

Seçilen tabaka kalınlıklarının kontrolünün yapılabilmesi maksadıyla, Tablo 3'den plentmix kırmataş temel için $\mathrm{CBR}=120$ ve kırmataş alt temel için $\mathrm{CBR}=50$ seçilerek, plentmix kırmataş temel için $\mathrm{M}_{\mathrm{R}}=180.000 \mathrm{psi}$ ve alt temel için $\mathrm{M}_{\mathrm{R}}=75.000 \mathrm{psi}$ olarak hesaplanır. $\mathrm{M}_{\mathrm{R}}$ değeri hesaplandıktan sonra, bu tabakalar üstünde gerekli Denklem 1 bağıntı yardımı ile plentmix kırmataş temel için $\mathrm{SN}_{1}=1,91$ inç $(4,85 \mathrm{~cm})$, kırmataş alt temel için $\mathrm{SN}_{2}$ $=2,69$ inç $(6,83 \mathrm{~cm})$ olarak hesaplanmıştır. Denklem 2'de, izafi mukavemet katsayıları ve tabaka kalınlıkları kullanılarak yapılan kontrolde, saf zeminlerde, kırmataş temel için 9,62 > 4,85 ve kırmataş alttemel için 11,87>6,83 olduğu, benzer şekilde $\% 10 \mathrm{C}$ içeren zeminler kırmataş temel için 7,78> 4,85 ve kırmataş alttemel için 10,03 >6,83 olduğu için esnek tabaka kalınlıklarının yeterli olduğu görülmüştür. Saf ve \%10C katkılı

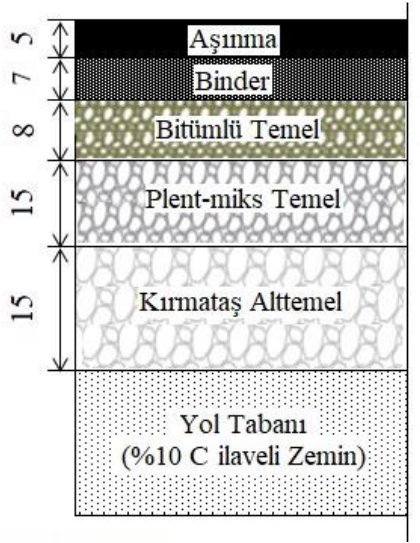

laveli Zemin için Seçilen Tabaka Kalınlıkları zemin için belirlenen üstyapı tabaka kalınlıkları toplamı sırasıyla $59 \mathrm{~cm}$ ve $50 \mathrm{~cm}$ olarak belirlenmiştir. Yapılan hesaplamada; \%10C içeren zeminler için üstyapı kalınlığında saf zemine kıyasla \%15,25 oranında azalma olduğu tespit edilmiştir.

\subsection{Esnek Üstyapı Ekonomik Analizi}

Siyah karbon ile stabilize edilmiş zeminin karayolu esnek üstyap1 maliyetleri üzerindeki etkisi, Karayolları Genel Müdürlüğü (KGM) verileri esas alınarak değerlendirilmiştir. KGM tarafından yayınlanmış olan birim fiyat cetvellerinde, alt temel ve temel tabakaları için birim ağırlık (ton) ve birim hacim $\left(\mathrm{m}^{3}\right)$ maliyetleri; bitümlü temel, binder ve aşınma tabakaları için birim alan $\left(\mathrm{m}^{2}\right)$ maliyetleri yayınlanmıştır. Çalışmada, karayolu 
üstyapılarının ekonomik analizi için 2020 yılı KGM birim fiyatları kullanılmıştır.

Yapılan hesaplamalar ve maliyet analizine göre; 1 günlük kür uygulanan zemin numunelerinin esnek yol üstyap1 kalınlığının $\mathrm{m}^{2}$ cinsinden birim maliyetleri Tablo 14 ve 15 ' de verilmiştir. Saf zemin ve \%10 C ilave edilerek güçlendirilen zemin için tabaka kalınlıkları ve maliyetleri karşılaştırma grafiği Şekil 13'de görülmektedir.

Tablo 14: 1 Günlük Kür Uygulanan Saf Zemin için Tabaka Kalınlıkların Birim Maliyetleri

\begin{tabular}{|c|c|c|c|c|c|}
\hline \multirow{2}{*}{ Poz no } & \multirow{2}{*}{ Tanım } & \multirow{2}{*}{ Birim } & \multirow{2}{*}{$\begin{array}{c}\text { Birim } \\
\text { Fiyat (TL) }\end{array}$} & \multicolumn{2}{|c|}{ Maliyet (TL) } \\
\hline & & & & $\mathrm{m}^{2} / \mathrm{cm}$ & $\mathrm{m}^{2}$ \\
\hline KGM/6405/S-M & $\begin{array}{l}5 \mathrm{~cm} \text { sıkışmış kalınlıkta } 1 \mathrm{~m}^{2} \text { asfalt betonu } \\
\text { aşınma tabakası yapımı }\end{array}$ & $\mathrm{m}^{2}$ & 15,12 & 3,02 & 15,12 \\
\hline KGM/6308 & $\begin{array}{c}8 \mathrm{~cm} \text { sıkışmış kalınlıkta } 1 \mathrm{~m}^{2} \text { asfalt betonu } \\
\text { binder tabakası yapımı }\end{array}$ & $\mathrm{m}^{2}$ & 18,29 & 2,29 & 18,29 \\
\hline KGM/6212 & $\begin{array}{l}12 \mathrm{~cm} \text { sıkışmış kalınlıkta } 1 \mathrm{~m}^{2} \text { asfalt betonu } \\
\text { bitümlü sıcak temel tabakası yapımı }\end{array}$ & $\mathrm{m}^{2}$ & 25,88 & 2,16 & 25,88 \\
\hline KGM/6100/3 & $\begin{array}{l}\text { plentmix temel yapılmas1 } \\
(\text { kaplama yoğ : } 2,4 \mathrm{~g} / \mathrm{cm} 3)\end{array}$ & ton & 53,21 & 1,28 & 19,16 \\
\hline KGM/6000 & $\begin{array}{l}\text { ocak taşından konkasörle kırılmış ve elenmiş } \\
\text { malzeme ile alt temel yapılması }\end{array}$ & $\mathrm{m}^{3}$ & 47,88 & 0,48 & 9,57 \\
\hline
\end{tabular}

Toplam: $88,02 \mathrm{TL}$

Tablo 15: 1 Günlük Kür Uygulanan \% 10C İlaveli Zemin için Tabaka Kalınlıkların Birim Maliyetleri

\begin{tabular}{|c|c|c|c|c|c|}
\hline \multirow{2}{*}{ Poz no } & \multirow{2}{*}{ Tanım } & \multirow{2}{*}{ Birim } & \multirow{2}{*}{$\begin{array}{c}\text { Birim } \\
\text { Fiyat (TL) }\end{array}$} & \multicolumn{2}{|c|}{ Maliyet (TL) } \\
\hline & & & & $\mathrm{m}^{2} / \mathrm{cm}$ & $\mathrm{m}^{2}$ \\
\hline KGM/6405/S-M & $\begin{array}{c}5 \mathrm{~cm} \text { sıkışmış kalınlıkta } 1 \mathrm{~m}^{2} \text { asfalt betonu } \\
\text { aşınma tabakası yapımı }\end{array}$ & $\mathrm{m}^{2}$ & 15,12 & 3,02 & 15,12 \\
\hline KGM/6308 & $\begin{array}{l}\text { 8cm sıkışmış kalınlıkta } 1 \mathrm{~m}^{2} \text { asfalt betonu } \\
\text { binder tabakası yapımı }\end{array}$ & $\mathrm{m}^{2}$ & 18,29 & 2,29 & 18,29 \\
\hline KGM/6211 & $\begin{array}{l}11 \mathrm{~cm} \text { sıkışmış kalınlıkta } 1 \mathrm{~m}^{2} \text { asfalt betonu } \\
\text { bitümlü sıcak temel tabakası yapımı }\end{array}$ & $\mathrm{m}^{2}$ & 23,76 & 2,16 & 23,76 \\
\hline KGM/6100/3 & $\begin{array}{c}\text { plentmix temel yapılmas } 1 \\
(\text { kaplama yoğ }: 2,4 \mathrm{~g} / \mathrm{cm} 3)\end{array}$ & ton & 53,21 & 1,28 & 19,16 \\
\hline KGM/6000 & $\begin{array}{l}\text { ocak taşından konkasörle kırılmış ve elenmiş } \\
\text { malzeme ile alt temel yapılması }\end{array}$ & $\mathrm{m}^{3}$ & 47,88 & 0,48 & 7,18 \\
\hline
\end{tabular}

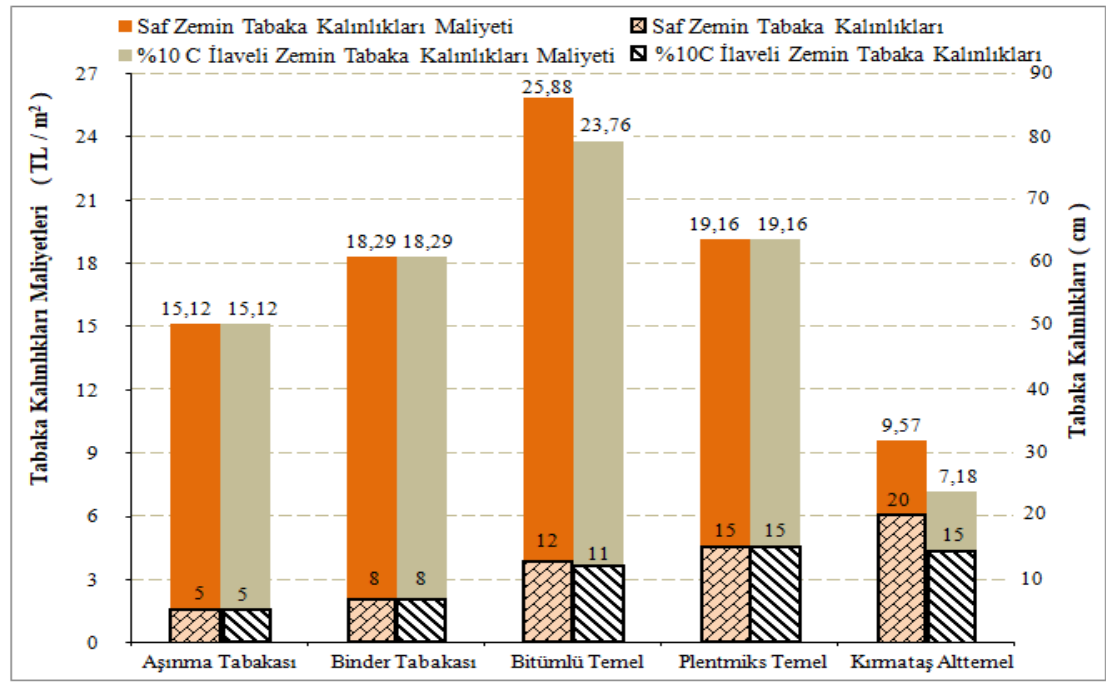

Şekil 13: 1 Günlük Kür Uygulanan Saf ve \%10C İlaveli Zemin için Tabaka Kalınlıkları ve Maliyetleri

Yol üstyapıları maliyetleri saf zemin için $88,02 \mathrm{TL} / \mathrm{m}^{2}, \%$ $10 \mathrm{C}$ ilaveli zemin için $83,51 \mathrm{TL} / \mathrm{m}^{2}$ olarak tespit edilmiştir. Tabaka kalınlıklarının maliyetleri göz önüne alındığında $\% 5,13$ oranında yapım maliyetinin azaldığı görülmektedir. $\mathrm{Bu}$ hesaplamalara göre $1000 \mathrm{~m}$ uzunluğunda ve $20 \mathrm{~m}$ genişliğindeki bölünmüş bir yolda yol taban zemininin; \%10 C ile iyileştirilme yapılması durumunda 147.009,45 TL tasarruf sağlanmış olacaktır.

Benzer şekilde yapılan hesaplamalar ve maliyet analizine göre; 7 günlük kür uygulanan zemin numunelerinin esnek yol üstyapı kalınlığının $\mathrm{m}^{2}$ cinsinden birim maliyetleri Tablo 16 ve 17 'de verilmiştir. Saf zemin ve $\% 10$ C ilave edilerek güçlendirilen zemin için tabaka kalınlıkları ve maliyetleri 
karşılaştırma grafiği Şekil 14'de görülmektedir

Tablo 16: 7 Günlük Kür Uygulanan Saf Zemin için Tabaka Kalınlıkların Birim Maliyetleri

\begin{tabular}{|c|c|c|c|c|c|}
\hline \multirow{2}{*}{ Poz no } & \multirow{2}{*}{ Tanım } & \multirow{2}{*}{ Birim } & \multirow{2}{*}{$\begin{array}{l}\text { Birim } \\
\text { Fiyat }\end{array}$} & \multicolumn{2}{|c|}{ Maliyet (TL) } \\
\hline & & & & $\mathrm{m}^{2} / \mathrm{cm}$ & $\mathrm{m}^{2}$ \\
\hline KGM/6405/S-M & $\begin{array}{c}5 \mathrm{~cm} \text { sıkışmış kalınlıkta } 1 \mathrm{~m}^{2} \text { asfalt betonu } \\
\text { asınma tabakası vapımı }\end{array}$ & $\mathrm{m}^{2}$ & 15,12 & 3,02 & 15,12 \\
\hline KGM/6308 & $\begin{array}{c}8 \mathrm{~cm} \text { sıkışmış kalınlıkta } 1 \mathrm{~m}^{2} \text { asfalt betonu } \\
\text { binder tabakası yapımı }\end{array}$ & $\mathrm{m}^{2}$ & 18,29 & 2,29 & 18,29 \\
\hline KGM/6212 & $\begin{array}{l}12 \mathrm{~cm} \text { sıkışmış kalınlıkta } 1 \mathrm{~m}^{2} \text { asfalt betonu } \\
\text { bitümlü sıcak temel tabakası yapımı }\end{array}$ & $\mathrm{m}^{2}$ & 25,88 & 2,16 & 25,88 \\
\hline KGM/6100/3 & $\begin{array}{l}\text { plentmix temel yapılmas1 } \\
\text { (kaplama yoğ : } 2,4 \mathrm{~g} / \mathrm{cm} 3 \text { ) }\end{array}$ & ton & 53,21 & 1,28 & 19,16 \\
\hline KGM/6000 & $\begin{array}{l}\text { ocak taşından konkasörle kırılmış ve elenmiş } \\
\text { malzeme ile alt temel yapılması }\end{array}$ & $\mathrm{m}^{3}$ & 47,88 & 0,48 & 9,10 \\
\hline
\end{tabular}

Toplam: 87,54 TL

Tablo 17: 7 Günlük Kür Uygulanan \% 10C İlaveli Zemin için Tabaka Kalınlıkların Birim Maliyetleri

\begin{tabular}{|c|c|c|c|c|c|}
\hline \multirow{2}{*}{ Poz no } & \multirow{2}{*}{ Tanım } & \multirow{2}{*}{ Birim } & \multirow{2}{*}{$\begin{array}{l}\text { Birim } \\
\text { Fiyat }\end{array}$} & \multicolumn{2}{|c|}{ Maliyet (TL) } \\
\hline & & & & $\mathrm{m}^{2} / \mathrm{cm}$ & $\mathrm{m}^{2}$ \\
\hline KGM/6405/S-M & $\begin{array}{c}5 \mathrm{~cm} \text { sıkışmış kalınlıkta } 1 \mathrm{~m}^{2} \text { asfalt betonu } \\
\text { aşınma tabakası yapımı }\end{array}$ & $\mathrm{m}^{2}$ & 15,12 & 3,02 & 15,12 \\
\hline KGM/6307 & $\begin{array}{c}7 \mathrm{~cm} \text { sıkışmış kalınlıkta } 1 \mathrm{~m}^{2} \text { asfalt betonu } \\
\text { binder tabakası yapımı }\end{array}$ & $\mathrm{m}^{2}$ & 16,07 & 2,30 & 16,07 \\
\hline KGM/6208 & $\begin{array}{l}8 \mathrm{~cm} \text { sıkışmış kalınlıkta } 1 \mathrm{~m}^{2} \text { asfalt betonu } \\
\text { bitümlü sıcak temel tabakası yapımı }\end{array}$ & $\mathrm{m}^{2}$ & 17,43 & 2,18 & 17,43 \\
\hline KGM/6100/3 & $\begin{array}{c}\text { plentmix temel yapilmas1 } \\
\text { (kaplama yoğ }: 2,4 \mathrm{~g} / \mathrm{cm} 3)\end{array}$ & ton & 53,21 & 1,28 & 19,16 \\
\hline KGM/6000 & $\begin{array}{l}\text { ocak taşından konkasörle kırılmış ve elenmiş } \\
\text { malzeme ile alt temel yapılması }\end{array}$ & $\mathrm{m}^{3}$ & 47,88 & 0,48 & 7,18 \\
\hline
\end{tabular}

Şekil 14: 7 Günlük Kür Uygulanan Saf ve \%10C İlaveli Zemin için Tabaka Kalınlıkları ve Maliyetleri

Yol üstyapıları maliyetleri saf zemin için $87,54 \mathrm{TL}, \% 10 \mathrm{C}$ ilaveli zemin için 74,96 TL olarak tespit edilmiş̧ir. Tabaka kalınlıklarının maliyetleri göz önüne alındığında \%14,37 oranında yapım maliyetinin azaldığı görülmektedir. $\mathrm{Bu}$ hesaplamalara göre $1000 \mathrm{~m}$ uzunluğunda ve $20 \mathrm{~m}$ genişliğindeki bölünmüş bir yolda yol taban zemininin; \%10 C ile iyileştirilme yapılması durumunda 251.648,00 TL tasarruf sağlanmış olacaktır. 


\section{Sonuç ve Öneriler}

Zayıf bir yol taban zemininin, atık araç lastiklerden elde edilen siyah karbon ile stabilizasyonu için kullanılması durumunda, esnek yol üst yapısı kalınlık ve maliyetine etkilerinin araştırıldığı bu çalışmada elde edilen sonuçlar aşağıda ifade edilmiştir.

1.Standart proktor deneyi sonucunda; siyah karbon oranı artıkça optimum su içerikleri değerinin arttığı ve maksimum kuru birim hacim ağırlığı değerinin azaldığı, bu sonuçların siyah karbonun boşluklu yapısının karışımın absorbe kapasitesini arttırması nedeniyle meydana geldiği değerlendirilmektedir.

2. Siyah karbon miktarının artmasıyla numunelerde birim şekil değiştirmenin azaldığı, bunun siyah karbonun numunelerin sertliğini arttırması sebebiyle meydana geldiği düşünülmektedir.

3. Serbest basınç deneyi sonuçlarında ise; siyah karbon ile güçlendirilen zeminlerde en büyük mukavemet değeri 1 ve 7 günlük kür sonunda $\% 10 \mathrm{C}$ ilaveli numunelerde tespit edilmiştir. Saf zemine göre mukavemet değerinin 1 ve 7 günlük kür sonunda sırasıyla 1,82 ve 2,14 kat arttığ1 görülmüştür. Mukavemet değerindeki bu önemli artış, siyah karbonun zeminlerin kohezyon kuvveti ve kayma direnci üzerinde önemli bir etkiye sahip olduğunu göstermektedir.

3. CBR deney sonuçlarına göre; \%10 katkılı zeminlerin 1 ve 7 günlük kür süreleri sonundaki $C B R$ değerleri, saf zemine kıyasla sırasıyla 1,28 ve 1,77 kat artış göstermiştir. Bu artış siyah karbonun zeminlerin taşıma gücü üzerinde önemli bir artışa sahip olduğunu göstermektedir. Ayrıca, kür süresinin bu artışta önemli bir etkiye sahip olduğu görülmüştür.

4. Yol üst yapısı tasarım sonuçlarına göre, \%10 C katkılı zeminler için hesaplanan üstyapı kalınlığının saf zemine kıyasla, 1 ve 7 günlük kür süreleri için sırasıyla $\% 10$ ve $\% 15,25$ oranında azaldığ 1 tespit edilmiştir. Bu azalmanın siyah karbonun zeminin taşıma gücü üzerindeki olumlu etkisinden kaynaklandığ görülmüştür.

5. Maliyet analizi sonuçlarına göre, \%10C katkılı zeminler üzerine inşa edilecek üstyapı maliyetlerinin saf zemine kıyasla özellikle 7 günlük kür süresi için \%14,37 azaldığı tespit edilmiştir. Bu hesaplamalara göre $1000 \mathrm{~m}$ uzunluğunda ve $20 \mathrm{~m}$ genişliğindeki bölünmüş bir yolda yol taban zemininin, \%10 C ile iyileştirilmesi durumunda üst yapı maliyetinde 251.648,00 TL tasarruf sağlanmış olacaktır.

Sonuç olarak, siyah karbonun yol taban zemininin stabilizasyonunda kullanılmasının zemin taşıma gücünü arttırarak esnek üst yapı tabaka kalınlığını ve maliyetini azaltacağı, ayrıca çevrenin korunmasına ve ülke ekonomisine katkı sağlayacağı değerlendirilmektedir.

\section{Kaynakça}

[1] Keskin, (2004), Kireç Stabilizasyonu ve Yol Kesitine Etkileri, Kocaeli Üniversitesi, FBE, Yüksek Lisans Tezi.

[2] Basha, E. A., Hashim, R., Mahmud, H. B., Muntohar, A. S., (2005), Stabilization of Residual Soil with Rice Husk Ash and Cement, Construction and Building Materials, 19, 448453.

[3] Akbulut, S., Arasan, S., Ekrem Kalkan, E. (2007). Modification of clayey soils using scrap tire rubber and synthetic fibers. Applied Clay Science, 38, 23-32.

[4] Brooks, R.M., (2009), Soil Stabilization with Fly Ash and Rice Husk Ash, International Journal of Research and
Reviews in Applied Sciences, ISSN: 2076-734X, EISSN: 2076-7366 Volume 1, Issue 3 (December 2009), 209-217.

[5] Keskin, S. ve Laman, M. (2012). Atık lastik - kum karışımlarının kayma mukavemetinin laboratuar deneyleriyle incelenmesi. Çukurova Üniversitesi Mühendislik Mimarlık FakültesiDergisi,27(2), 27-35.

[6] Shabana S., Anshi C., Shamseera P., Shyamili T. M., Sruthi V., Suhaira P. (2014) "Study on CBR values of soll with crushed coconut shells" International Journal of Advanced Engineering Technology Volume: 05 Issue: 03 | JulySeptember 2014, Pages 55-58.

[7] Yarbaşı, N. (2016). Atık lastik parçaları ile güçlendirilmiş killi zeminlerin donma-çözülme davranışı. Pamukkale Üniversitesi Mühendislik Bilimleri Dergisi, 22(6), 559-562.

[8] Karaman, M. ve Ecemiş, N. (2017, Kasım 22-24). Kum lastik kırpıntı çapının ve karışım oranının sıvılaşma potansiyeline etkisinin sarsma tablası deneyleri ile incelenmesi. 7. Geoteknik Sempozyumu, İstanbul.

[9] Işık, F. ve Akbulut R.K. (2018). Geri Dönüştürülmüş Karbon Karasının Killi Zeminlerin Kıvam Limitlerine Etkisi. / Iğdır Univ. J. Inst. Sci. \& Tech. 8(2): 123-130, 2018

[10] Kumar S.N, Reddy A. S. T., A. Kumar P.V., (2019), "Utilization Of Carbon Black Waste For Subgrades In Flexible Pavements" International Journal Of Scientıfic \& Technology Research volume 8, Issue 12, December 2019, Pages 1817-1820

[11] Eryılmaz H. ve Demirarslan K.O. “Ömrünü tamamlamış lastiklerin (ÖTL) sıvılaştırılarak geri dönüşümünün araştırılması". Sürdürülebilir Mühendislik Uygulamaları ve Teknolojik Gelişmeler Dergisi, 2(1): 50-56, (2019).

[12] Anonim. https://eracevre.com/pdf/Carbon_Black_Brochure.pdf "Green Karbon Black” (Erişim Tarihi:25.09.2020)

[13] Yılmaz.I, Yıldıran M., Keskin İ. (2017), Zemin Mekaniği Laboratuvar Deneyleri ve Çözümlü Problemler, Seçkin Kitabevi Ankara.

[14] AASHTO (1993). Interim Guide For Design of Pavement Structures, American Association of State Highway and Transportation Officials, Washington, D.C.

[15] Kök B.V. (2019), Karayolu Mühendisliği ve Tasarımı, Nobel Akademik Yayıncılık Ankara

[16] Karayolları Esnek Üstyapıları Projelendirme Rehberi (2008). T.C. Ulaştırma Bakanlığı Karayolları Genel Müdürlüğü Teknik Araştırma Dairesi Başkanlığı Üstyap1 Şubesi Müdürlüğü, Ankara

[17] Karbon Karaları ve Testleri(2011). Kimya Teknolojisi, Milli Eğitim Bakanlığı (524KI0246), Ankara.

[18] Kızıltaş, Ü., 1999, Lastik Üretiminde Katkı Elemanlarının Özelliklere Etkisi, Yüksek Lisans Tezi, Yıldız Teknik Üniversitesi Fen Bilimleri Enstitüsü, İstanbul, 64s.

[19] Geçkil, T., 2008, Siyah Karbonun Bitümlü Sıcak Karışımların Özelliklerine Etkisinin Araştırılması, Doktora Tezi, Fırat Üniversitesi, Elazığ.

[20] Tunç, A. 2004. Kaplama Mühendisliği ve Uygulamaları. Asil Yayın Dağıtım, Ankara. 